\title{
Supervisi Pembelajaran Sebagai Pengembangan Budaya Mutu Guru
}

\author{
Andi Arif Rifa'i \\ Fakultas Tarbiyah \\ IAIN Syaikh Abdurrahman Siddik Bangka Belitung \\ Bangka, Indonesia \\ andiarifrifai@gmail.com
}

\begin{abstract}
Abstract

The teacher is educator who has advantages as well as limitations as ordinary humans. Therefore he needs other people (supervisor) to help him minimize his weaknesses, so that his professional abilities are formed. In addition, supervision activitiy also aim to guarantee the quality of learning that has an impact on the quality of graduates. This means that supervision serves as a quality assurance aimed at establishing quality culture of teacher. Teachers with a high quality culture will lead to the achievement of the quality of learning and education and determine the quality and competitiveness of graduates.
\end{abstract}

Keywords: instructional supervision, professional ability, quality culture

Abstrak

Guru merupakan sosok pendidik yang memiliki kelebihan sekaligus keterbatasanketerbatasan sebagaimana manusia biasa. Oleh karenanya ia membutuhkan orang lain dalam hal ini supervisor guna membantunya meminimalisir kelamahan-kelamahannya sehingga terbentuk kemampuan profesionalnya. Selain itu, kegiatan supervisi juga bertujuan untuk menjamin mutu pembelajaran yang imbasnya pada mutu lulusan. Artinya supervisi berfungsi sebagai penjaminan mutu yang ditujukan untuk terbentuknya budaya mutu guru. Guru-guru dengan budaya mutu yang baik akan membawa pada pencapaian mutu pembelajaran maupun pendidikan dan menentukan kualitas serta daya saing lulusan.

Kata Kunci: supervisi pembelajaran, kemampuan professional, budaya mutu

\section{A. Pendahuluan}

Pendidikan merupakan sebuah program yang harus direncanakan dengan baik dan sistematis. Sebagai sebuah program, pendidikan pada hakekatnya berupa aktivitas sadar dan sengaja yang diarahkan untuk mencapai tujuan pendidikan. ${ }^{1}$ Tujuan tersebut hanya dapat tercapai secara efektif apabila dilakukan upaya

\footnotetext{
${ }^{1}$ Purwanto, Evaluasi Hasil Belajar (Yogyakarta: Pustaka Pelajar, 2009).hlm.1
} 
bersama (collective effort) dari seluruh unsur yang ada dalam sebuah lembaga pendidikan. Usaha tersebut dapat berjalan serasi-seimbang serta efektif-efisien apabila diterapkan manajemen (pengelolaan) lembaga dengan baik sejalan dengan konsep-konsep manajerial yang telah teruji.

Dalam konsep manajerial, program-program pendidikan yang ada tidak dapat dipisahkan (diceraikan) dari upaya pengembangan. Tanpa adanya upaya pengembangan lembaga pendidikan kita akan tertinggal dari lembaga-lembaga pendidikan yang ada di negara lain. Oleh karenanya, untuk dapat melakukan pengembangan dengan baik, seorang pemimpin lembaga pendidikan harus melakukan evaluasi dan supervisi untuk perbaikan dan pengembangan. Upaya tersebut harus dilakukan secara berkelanjutan dan terprogram, dan apabila dikaitkan dengan proses perbaikan mutu pendidikan maka diperlukan upaya perbaikan mutu secara berkelanjutan (continuous quality improvement).

Continuous quality improvement atau dapat disebut sebagai budaya mutu (quality culture), sudah sepatutnya ditanamkan pada sosok guru professional, sehingga persoalan-persoalan mutu pendidikan (yang disebut Bahrul Hayat sebagai "problematik paradoks") pada era globalisasi dapat diselesaikan dengan cepat, artinya mutu pendidikan (the pursuit of excellence) yang ada disesuaikan dengan rujukan mutu (banchmarking) kompetensi global agar tidak tersisih dari persaingan antar bangsa. Di sisi lain pendidikan kita juga dituntut menimbang mutu dalam keragaman dan kearifan lokal agar siswa hidup dengan menapak di bumi sendiri. ${ }^{2}$

Peningkatan mutu pendidikan hakekatnya menuntut adanya peran aktif supervisor maupun kepala sekolah dalam melakukan pembinaan atau pengawasan kerja guru secara berkesinambungan menuju tumbuh kembangnya budaya mutu. Konsep dari budaya mutu itu sendiri pada dasarnya berhubungan dengan kondisi dari unjuk kerja tugas (kinerja) atau prestasi terbaik dalam pencapaian tujuan. Budaya mutu menurut pandangan Brings (2010) terbentuk dari; nilai, keyakinan, sikap, komitmen, ekspektasi, kesepakatan (agreement), kapasitas, negosiasi, partisipasi, persatuan (unity) dan kepercayaan. ${ }^{3}$ Sejalan dengan itu, maka budaya mutu yang telah berkembang pada lingkungan professional seperti guru, akan membawa pada pencapaian tujuan pendidikan atau pembelajaran secara efektif, efisien dan berkualitas tinggi yang pada akhirnya menciptakan daya saing lulusannya.

\section{B. Prinsip-prinsip Supervisi Pembelajaran}

Supervisi pembelajaran (instructional supervision) merupakan kegiatan pembinaan pengajaran guru guna meningkatkan mutu pembelajaran. Supervisi pengajaran di indonesia, dalam prakteknya selama ini dilakukan oleh penilik atau pengawas dan sebagiannya oleh kepala sekolah. Acheson dan Gall memaknai

\footnotetext{
${ }^{2}$ Bahrul Hayat and Suhendra Yusuf, Benchmark Internasional Mutu Pendidikan (Jakarta: Bumi Aksara, 2010).hlm.3

${ }^{3}$ Isara Tongsamsi et al., "A Structural Equation Model of Factors Influencing the Quality Culture of the Workforce in Thailand Public Higher Education Institutions," International Journal of Education 4, no. 4 (2012): 16-26.hlm.17
} 
kegiataan supervisi tersebut sebagai bentuk bantuan terhadap perbaikan performansi (kinerja) mengajar guru. Oleh sebab itu, kegiatan supervisi disebut Nerney sebagai prosedur pengawasan yang rasional dengan tujuan evaluasi yang dapat memberikan umpan balik bagi perbaikan proses mengajar. ${ }^{4}$ Dalam prakteknya supervisi menurut Oliva (1976:6) dapat dilakukan secara individual maupun kelompok yang pada dasrnya bertujuan untuk berkontribusi khusus dalam pengembangan pembelajaran guru. ${ }^{5}$

Tugas supervisi bukanlah tugas yang mudah, dibutuhkan keahlian-keahlian khusus guna mencapai efektifitas yang baik. Oleh karena itu, Sam dan Tuti (2005:90) berpendapat bahwa supervisi harus dilakukan oleh seorang ahli (expert), karena layanan dasar yang diberikan oleh supervisor bertujuan untuk mengembangkan secara kooperatif seluruh faktor yang berpengaruh pada pertumbuhan dan perkembangan anak (peserta didik). ${ }^{6}$ Supervisor dalam kegiatan supervisi pengajaran atau pembinaan pengajarannya bertujuan untuk memberikan bantuan kepada guru dengan melakukan evaluasi dan memberikan umpan balik yang mengarah pada perbaikan proses belajar mengajar di kelas. Adapun prinsipprinsip yang perlu diperhatikan dalam melakukan supervisi antara lain;

1. Harus bersifat konstruktif

2. Harus didasarkan atas keadaan dan kenyataan yang sebenarnya (fakta)

3. Harus sederhana dan informal dalam pelaksanaannya

4. Harus dapat memberikan perasaan aman kepada para guru dan pegawai yang disupervisi

5. Harus didasarkan atas hubungan profesional

6. Harus memperhitungkan kesanggupan, sikap, mungkin prasangka guruguru dan pegawai sekolah

7. Tidak bersifat mendesak (menekan) atau otoriter.

8. Tidak boleh didasarkan atas kekuasaan pangkat, kedudukan, dan kekuasaan pribadi

9. Tidak boleh terlalu cepat mengharapkan hasil dan tidak boleh terlalu cepat merasa kecewa

10. Hendaknya juga bersifat preventif, korektif dan kooperatif. ${ }^{7}$

Pelaksanaan pembinaan (supervisi) sebagaimana prinsip-prinsip di atas, pada tataran implementatifnya dapat bersifat positif maupun negatif. Tahlele (dalam Warisan, 2003:16) memberikan pengelompokan perbedaan secara jelas dan tegas, antara supervisi positif dengan supervisi negatif, ciri-ciri pembedanya sebagai berikut:

\footnotetext{
${ }^{4}$ Willem Mantja, Bahan Ajar Pembinaan/Supervisi Pengajaran (Malang: PPS UM, 2000).hlm.1

${ }^{5}$ Peter F. Oliva, Supervision for Today's Schools (Helper \& Row, Publisher Inc, 1976).hlm.6

${ }^{6}$ Sam M. Chan and Tuti R. Semiawan, Kebijakan Pendidikan Era Otonomi Daerah (Jakarta: Rajawali Pres, 2005).hlm.90

${ }^{7}$ Ngalim Purwanto, Prinsip-Prinsip Dan Teknik Evaluasi Pengajaran (Bandung: Remaja Rosdakarya, 2006).hlm.20
} 
1. Supervisi positif, memiliki ciri: demokratis dan kooperatif, kreatif dan konstruktif, ilmiah, memberikan rasa nyaman pada guru, berdasarkan pada realitas, memberikan kesempatan pada supervisor dan guru-guru untuk mengadakan self evaluation.

2. Supervisi negatif memiliki ciri; bersifat otoriter, mencari-mencari kesalahan guru, supervisor menganggap dirinya lebih tinggi karena jabatan, supervisor sebagai seorang inspektur, dan supervisor cepat merasa kecewa bila guru mengalami kegagalan. ${ }^{8}$

Secara garis besar, prinsip dari supervisi guru (pengajaran guru) adalah pembinaan secara demokratis, kooperatif, konstruktif, ilmiah dan realistis terhadap pengembangan kompetensi professional guru dan pencapaian tujuan instruksional serta tujuan sekolah secara efektif dan efisien. Supervisi pembelajaran berperan sebagai katalisator pengembangan professional guru melalui peningkatan mutu pembelajaran secara berkelanjutan (continuous instructional quality improvement/ $C I Q I)$.

\section{Fungsi dan Peran Supervisi dalam Pengembangan Pengajaran Guru}

Sejalan dengan beberapa definisi di atas, bahwa supervisi pengajaran merupakan usaha melakukan pengembangan dan peningkatan performansi pengajaran guru maka supervisi selain memiliki prinsip, juga memiliki fungsi, dimana hakekat fungsi supervisi adalah memberikan bantuan terhadap program pendidikan melalui berbagai macam cara guna peningkatan mutu pendidikan. Sweringen berpendapat bahwa fungsi supervisi diantaranya;

1. Mengkoordinasi semua usaha sekolah.

2. Memperlengkapi kepemimpinan sekolah.

3. Memperluas pengalaman guru.

4. Menstimulir usaha-usaha yang kreatif.

5. Memberikan fasilitas dan penilaian yang terus menerus.

6. Menganalisa situasi belajar mengajar.

7. Serta memberikan pengetahuan dan skill terhadap anggota staf. ${ }^{9}$

Fungsi-fungsi di atas menurut Pidarta dapat dikelompok menjadi dua, yaitu; Pertama, disebut dengan istilah fungsi utama, yaitu membantu sekolah mewakili pemerintah dalam usaha menapai tujuan pendidikan (membantu perkembangan individu siswa). Kedua, fungsi tambahan, yaitu membantu sekolah dalam membina guru-guru agar dapat bekerja dengan baik dan dalam mengadakan kontak dengan masyarakat dalam rangka menyesuaikan diri dengan tuntutan masyarakat. ${ }^{10}$

\footnotetext{
${ }^{8}$ Warisan, "Hubungan Supervisi Pengajaran Dan Motivasi Kerja Dan Kinerja Guru SMU Negeri Kabupaten Pasuruan” (Tesis, Universitas Negeri Malang (UM), 2003).hlm.16

${ }^{9}$ Warisan.hlm.16

${ }^{10}$ Warisan.hlm.20
} 
Berdasarkan pada fungsi supervisi maka peran supervisor (pengawas atau pembina) adalah memberikan support (supporting), membantu (assisting), dan mengikutsertakan. ${ }^{11}$ Dengan demikian, peran supervisor secara nyata adalah menciptakan suasana kondusif, dengan tujuan agar guru-guru merasa aman dan bebas dalam mengembangkan potensi dan daya kreasinya dengan penuh tanggung jawab. Lebih tegas, Mantja (2000:40) mengatakan bahwa peran supervisi lebih sebagai tindakan dan eksperimentasi yang memiliki tujuan untuk meningkatkan pengajaran dan program pembelajaran. ${ }^{12}$ Meskipun pada dasarnya, seorang guru telah berijazah sarjana (S1), namun menurut Pidarta (2009) masih perlu mendapatkan pembinaan dari supervisor, sebab adanya ketidak imbangan antara perkembangan profesi guru dengan perkembangan ilmu dan teknologi (iptek). Oleh karenanya, agar perkembangan profesi guru tidak jauh tertinggal maka diperlukan pembinaan oleh supervisor. ${ }^{13}$

Dari beberapa pandangan di atas, jelas terlihat bahwa supervisi berupaya melakukan pengembangan program belajar mengajar, memperluas pengalaman guru, pengembangan professional guru, memotivasi usaha-usaha kreatif guru, memberikan fasilitas dan penilaian terus menerus terhadap proses pengajaran, serta membina guru agar dapat bekerja sesuai dengan tuntutan zaman. Dengan demikian, peran dan fungsi supervisi pendidikan (pengajaran) adalah memberikan bantuan kepada guru untuk mengembangkan keterampilan dan daya kreativitasnya dalam proses belajar mengajar, serta mampu menjadi problem-solver bagi masalahmasalah yang timbul dalam proses belajar mengajarnya. Sehingga seorang supervisor tidak lagi ahli dalam mengintip guru dan memberikan penilaian administratif, namun ahli dalam membimbing guru untuk lebih berkompeten dan professional dalam bidangnya.

\section{Implementasi Supervisi Pembelajaran Guru oleh Kepala Sekolah}

Supervisi pada dasarnya merupakan bagian yang tidak dapat dipisahkan dari fungsi-fungsi administrasi (manajemen) pendidikan. Dimana, fungsi pokok dari manajemen pendidikan antara lain; perencanaan (planning), pengorganisasian (organizing), pengkoordinasian (coordinating), komunikasi (communicating), supervisi (supervising), kepegawaian (staffing), pembiayaan (budgeting), dan penilaian (evaluating). ${ }^{14}$ Supervisi dalam konteks manajerial sekolah, mendudukkan kepala sekolah sebagai supervisor yang berkawajiban membina para guru agar menjadi pendidik yang baik (professional). Bagi guru yang telah baik agar dapat dipertahankan kulitasnya (mutunya), dan bagi guru yang belum baik dapat dikembangkan lebih baik lagi. ${ }^{15}$

${ }^{11}$ Piet A. Sahertian and Frans Mataheru, Prinsip Dan Teknik Supervisi Pendidikan (Surabaya: Usaha Nasional, 1982).hlm.31

${ }^{12}$ Willem Mantja, Bahan Ajar Pembinaan/Supervisi Pengajaran.hlm.40

${ }^{13}$ Made Pidarta, Supervisi Pendidikan Kontekstual (Jakarta: Rineka Cipta, 2009).hlm.53

${ }^{14}$ Chan and Semiawan, Kebijakan Pendidikan Era Otonomi Daerah.hlm.81

${ }^{15}$ Made Pidarta, Supervisi Pendidikan Kontekstual.hlm.18 
Supervisi pembelajaran merupakan salah satu fungsi penting dalam administrasi (manajemen) pendidikan. Fungsi supervisi dalam pengelolaan sekolah, memiliki makna kontrol dalam upaya pencapaian tujuan sekolah. Sehingga sebagai seorang manajer sekolah, kepala sekolah memiliki tugas melakukan control atas upaya mencapai tujuan organisasi, salah satunya dengan melakukan pembinaan pengajaran guru melalui supervisi sebagai fungsinya. Halhal yang perlu dikembangkan dan diperhatikan dalam melakukan supervisi guru antara lain:

1. Kepribadian guru.

2. Peningkatan profesi secara kontinyu.

3. Proses pembelajaran.

4. Peningkatan profesi secara kontinu.

5. Penguasaan materi pelajaran.

6. Keragaman kemampuan guru.

7. Keragaman daerah.

8. Kemampuan guru dalam bekerjasama dengan masyarakat. ${ }^{16}$

Selain beberapa hal di atas, dalam melakukan supervisi pengajaran, hal penting yang juga perlu diperhatikan adalah teknik-teknik dalam melakukan supervisi yang baik. Sehubungan dengan itu, Negley dan Evans (1980:190) berpendapat, kunjungan kelas (classroom visitation) merupakan teknik pembinaan guru paling essensial, sebab faktanya observasi dan kunjungan kelas memiliki efektifitas yang tinggi dalam kegiatan pembinaan. ${ }^{17}$ Observasi kelas, dalam supervisi merupakan kegiatan mengamati dan memperhatikan secara teliti terhadap gejala yang tampak ketika kegiatan belajar mengajar berlangsung. ${ }^{18}$ Kegiatan ini ditujukan untuk menemukan permasalaham-permasalahan penghambat proses belajar-mengajar yang dapat ditangkap oleh supervisor, untuk dibicarakan (didiskusikan) dengan guru serta mencarikan penyelesaiannya.

Observasi kelas yang baik menurut Lipham dkk (1985:179) didasarkan parameter yang jelas, artinya supervisor menyusun terlebih dahulu parameter yang sesuai dengan fokus pembelajaran, menentukan kapan dan berapa lama observasi kelas itu berlangsung, apa tujuan pembelajaran dan bagaimana menilainya, sehingga supervisor (kepala sekolah, penilik, pengawas dan lain-lain) dalam supervisinya, tidak bertindak sebagai "penegak peraturan". ${ }^{19}$ Observasi kelas bertujuan untuk memperoleh gambaran menyeluruh mengenai program pembelajaran serta memperoleh informasi yang akan digunakan untuk

\footnotetext{
${ }^{16}$ Made Pidarta.hlm.18

${ }^{17}$ Negley and Evan, Handbook for Effective Supervision of Instruction (Engglewood Cliffs: Prentice Hall Inc, 1980).hlm.190

${ }^{18}$ Burhanudddin, Analisis Administrasi Dan Kepemimpinan Pendidikan (Jakarta: Bumi Aksara, 1994).hlm.328

${ }^{19}$ Lipham, James M., Rankin, Robb E., and Hoeh Jr, James A., The Principalship; Concept, Competencies, and Cases (New York: Logman Inc, 1985).hlm.179
} 
menyelesaikan masalah-masalah pembelajaran. ${ }^{20}$ Artinya, dalam melakukan supervisinya, supervisor tidak hanya melakukan pengamatan (observasi) yang bersifat administratif maupun pemberian nilai, namun lebih pada sebuah pembinaan guru yang memerlukan persiapan matang, guna pencapaian maksimal tujuan pembinaannya.

Program pembinaan guru, mewajibkan seorang supervisor (pengawas atau kepala sekolah) mempertimbangkan kriteria-kriteria penting dalam observasinya sebagai berikut:

1. Memiliki tujuan yang jelas.

2. Mengungkapkan aspek-aspek yang dapat digunakan untuk memperbaiki dan meningkatkan kemampuan guru.

3. Menggunakan lembaran observasi.

4. Terjadi interaksi antara guru dan supervisor.

5. Tidak mengganggu proses pembelajaran.

6. Diikuti dengan tindak lanjut. ${ }^{21}$

Kriteria-kriteria di atas agar supervisor dalam observasi kelas dapat mendapatkan global picture dari program pembelajaran, dan juga memperoleh informasi yang akan digunakan dalam menyelesaikan instructional problems (masalah-masalah pembelajaran). Dengannya, pembinaan yang dilakukan dapat berdaya guna dalam meningkatkan mutu pembelajaran dan meningkatkan mutu sekolah.

Kepala sekolah sebagai pembina (supervisor) guru di sekolah, sebagaimana fungsinya sebagai menager sekolah, perlu memikirkan beberapa strategi dalam pembinaan guru. Strategi atau berpikir secara strategis lebih berupa proses untuk memahami dua hal pokok yang saling terkait: yaitu focus (fokus) dan timing (kesadaran atas waktu). Dalam hal ini, Fokus lebih mengacu pada kemampuan kita dalam menempatkan perhatian kita. Sedangkan, Keadaran waktu (timing) mengacu pada pemahaman akan dinamika perubahan yang sangat erat kaitannya dengan panjang-pendeknya waktu yang dibutuhkan untuk suatu perubahan. Sehingga, berfikir strategis mencakup bagaimana membuat perencanaan strategis dan implementasinya dalam pengembangan kelembagaan, khususnya pembinaan pengajaran guru. ${ }^{22}$ Kepala sekolah yang berfikir strategis dalam melakukan supervisi di sekolah sebaiknya direncanakan dengan matang dan berorientasi pada pengembangan budaya mutu guru, sebab dengan budaya mutu seorang guru secara berkelanjutan akan berdampak pada kapasitas guru dalam mengembangkan kemampuannya secara mandiri sesuai dengan tuntutan perkambangan zaman.

\section{E. Membangun Budaya Mutu Guru Melalui Supervisi Pembelajaran}

Budaya mutu dalam tataran bahasa, terdiri dari dua suku kata yaitu budaya dan mutu. Makna budaya secara etimologi merupakan pola dari susunan, materi

${ }^{20}$ Negley and Evan, Handbook for Effective Supervision of Instruction.hlm.190

${ }^{21}$ Depdikbud, Kurikulum Sekolah Dasar: Pedoman Pembinaan Guru (Jakarta: Departemen Pendidikan dan Kebudayaan, 1986).

${ }^{22}$ Andi Arif Rifa'i, "Berfikir Strategis: Kerangka Kerja Pengembangan Lembaga Pendidikan Islam," Jurnal Akademika: Jurnal Pemikiran Islam STAIN Metro 17, no. 2 (2012).hlm.1 
atau perilaku yang diadopsi oleh sebuah masyarakat atau kelompok. ${ }^{23}$ Sedangkan mutu (kualitas) memiliki arti yang subyektif, dimana setiap orang atau bidang memiliki makna yang berbeda. Mutu dapat juga dikatakan sebagai sebuah konsep yang selalu memiliki subjek pada konteks sejarah, ekonomi, nasional dan internasional. ${ }^{24}$ Budaya mutu menurut Brings (2010) memiliki unsur-unsur antara lain; nilai, keyakinan, sikap, komitmen, ekspektasi, kesepakatan (agreement), kapasitas, negosiasi, partisipasi, persatuan (unity) dan kepercayaan. ${ }^{25}$

Budaya mutu dalam konteks pendidikan, sebagaimana hasil riset yang dilakukan oleh Isara Tongsamsi dkk menunjukkan hasil bahwa budaya mutu secara langsung dipengaruhi oleh komitmen terhadap mutu (comitment to quality), persepsi pada level managerial dan kepercayaan pada hasil penilaian mutu pendidikan (trust in the education quality asessment result). Komitmen pada mutu sendiri dipengaruhi oleh kepercayaan pada hasil penilaian mutu pendidikan, komunikasi terkait penilaian mutu pendidikan (pengaruhnya rendah), dan partisipasi dalam penilaian mutu pendidikan. Secara garis besar, budaya mutu tidak berdiri sendiri, akan tetapi didukung (dipengaruhi) oleh faktor lain yang terkait dengannya. $^{26}$

Berdasarkan pada kajian di atas, bahwasannya budaya mutu dipengaruhi oleh faktor-faktor yang menjadi penentu terciptanya sebuah bangunan quality culture, maka langkah-langkah pengembangannya tidak dapat dicerabut dari faktor-faktor tersebut. Misalnya, dalam membangun budaya mutu maupun mengembangkan mutu secara berkelanjutan (Continuous Quality Culture Improvement), yang menjadi fokus garapannya pada dunia industri antara lain; kepemimpinan dan komitmen manajemen puncak, manajemen pelanggan, pendidikan dan pelatihan, tim kerja, pemberdayaan orang dan manajemen, kerjasama pemasok, kebijakan dan strategi mutu, proses manajemen, penghargaan dan pengakuan, dan komunikasi efektif (Wan Yusoff, et al, 2006:4-7). ${ }^{27}$ Sedangkan dalam dunia pendidikan, standar dan pedoman penjaminan mutu dapat dilihat penerapannya pada perguruan tinggi di Eropa, yangmana wilayah pengembangannya antara lain; konsep budaya mutu (quality culture concept), prinsip-prinsip utama manajemen mutu, teori organisasi pembelajaran, dan prinsipprinsip sistem informasi manajemen. ${ }^{28}$ Secara nyata, konsep terkait pengembangan budaya mutu merupakan satu hal terpenting dalam dunia pendidikan yang perlu

\footnotetext{
${ }^{23}$ Wan Yusoff Wan Mahmood et al., Development of Quality Culture in The Construction Industry (Malaysia: Universiti Teknologi Malaysia ICCI, 2006).hlm.2

${ }^{24}$ Inga Milisiunaite, Roma Adomaitiene, and Juozas Galginaitis, "Quality Management As A Tool For Quality Culture Embedment: Vilnius University Approach" (31st Annual EAIR Forum in Vilnius, Lithuania, 2009).hlm.4

${ }^{25}$ Tongsamsi et al., "A Structural Equation Model of Factors Influencing the Quality Culture of the Workforce in Thailand Public Higher Education Institutions."'hlm.17

${ }^{26}$ Tongsamsi et al.hlm.6

${ }^{27}$ Mahmood et al., Development of Quality Culture in The Construction Industry.hlm.4-7

${ }^{28}$ Milisiunaite, Adomaitiene, and Galginaitis, "Quality Management As A Tool For Quality Culture Embedment: Vilnius University Approach.”hlm.11
} 
mendapatkan sentuhan dari tangan profesional untuk dapat menumbuh kembangkannya.

Hampir sama dengan pandangan atau konsep budaya mutu yang dikembangkan pada dunia Industri di atas, Pariyaporn Tungkunanan dkk menjelaskan beberapa faktor yang mendukung terciptanya budaya mutu antara lain:

1. Kepemimpinan manajer; seorang pemimpin harus mampu menyampaikan visi, misi dan tujuan manajemennya secara jelas sehingga memotivasi bawahannya untuk bekerja dengan budaya mutu. Pemimpin juga harus mendorong bawahannya untuk berinovasi dalam mengimplementasikan manajemen mutu (quality management).

2. Manajemen berdasar fakta (management by fact); manajemen yang baik seharusnya berdiri di atas fakta (kebenaran), sehingga kita dapat membuat kebijakan secara efektif. Kebijakan-kebijakan harus dibuat secara akademis atau pendekatan ilmiah (scientific approach) dan logis.

3. Perencanaan strategis (strategic planning); memiliki keuntungan bagi organisasi dan anggota. Perencanaan strategis merupakan isntrumen kunci yang dapat membantu organisasi dan anggotanya menghadapi perubahan masa depan dengan melakukan persiapan (preparation). Anggota organisasi mengetahui secara jelas tujuan organisasi dan mengambil bagian dalam membuat tujuan.

4. Desentralisasi; manajemen organisasi berbasis pada desentralisasi yang dengan demokrasi dapat mendorong staff untuk berpartisipasi dalam pembuatan keputusan. Oleh karena itu, organisasi akan memiliki fleksibilitas dalam bekerja yang berhubungan dengan ekonomi, masyarakat dan budaya. Hal ini juga dapat meningkatkan capacity-bulding untuk kesadaran diri dan pengembangan diri (self develompent) yang tetap.

5. Pengembangan diri berkelanjutan; Guru harus belajar selama hidupnya dan mencari pengatahuan yang dapat menyelesaikan permasalahanpermasalahan dan melakukan pengembangan pengajaran berkelanjutan dengan belajar dari perpustakaan, masyarakat dan menggunakan cendekia lokal dan pengetahuan internet untuk pengembangan diri. Mereka harus mengikuti training (pelatihan) oleh trainer guru atau pakar yang berpengalaman mengajar. Mereka harus menjalani pelatihan yang berbeda dan harus mengikuti pendidikan tinggi (pendidikan lanjut) sejalan dengan tuntutan perubahan dunia.

6. Komitmen organisasi; komitmen organisasi dapat menggambarkan kesatuan dan partisipasi dalam aktifitas berbeda yang membuat anggota sulit untuk keluar. Komitmen adalah inti dari organisasi dalam arti membuat pemahaman antara organisasi dan anggota. Anggota merupakan orang yang memiliki komitmen organisasi, dapat mewujudkan tujuan dan nilai organisasi. 
7. Kerja tim; hak anggota organisasi memberi bantuan pada orang lain, berbagi pengetahuan dan memiliki kebebasan komunikasi, mereka dapat menggunakan berbagai sumber bersama secara efektif. Dengan kerjasama dalam membuat keputusan seperti penyelesaian masalah, anggota akan memiliki komitmen yang kuat terhadap tim, dan mereka tidak dapat menerima kegagalan tindakan (kerja). Konsekuensinya, mereka ingin bekerja dengan bermutu. Itulah mengapa kerja tim penting untuk anggota dan organisasinya.

8. Perhatian (kepedulian) pelanggan; pengembangan tidak dapat berharga jika pelanggan tidak puas dengan perubahan itu. Permintaan tidak hanya pada saat ia membeli sebuah produk tetapi permintaannya adalah kepuasan dari penggunaan produk sampai akhir masanya. Kutipan tersebut di atas merupakan ide penting dari teori mutu. Dengan demikian, sebuah manajemen organiasai berdasarkan pada standar pelanggan atau melebihi harapannya. Dapat dikatakan diamana metode pengajaran berpusat pada murid terfokus pada manfaat untuk siswa.

9. Perkembangan berkalnjutan; bertujuan untuk meningkatkan kemampuan murid yang mana merupakan kepuasaan masyarakat. Personel sekolah bekerja berdasarkan pada sebuah action plan dan investigation plan sama halnya sebuah asessment plan. Hasil penilaian dari keseluruhan proses harus dikembangkan secara berkelanjutan. ${ }^{29}$

Merubah budaya mutu pada dasarnya dapat dilakukan dengan terlebih dahulu merubah persepsi dan sikap terhadap pengembangan mutu itu sendiri. Merubah budaya merupakan bagian dari tujuan manajemen mutu terpadu (total quality management/TQM) ${ }^{30}$ Lebih lanjut, manajemen mutu (quality manajement) pada lembaga pendidikan itu sendiri hakekatnya bertujuan mengintegrasikan semua fungsi organisasi yang berfokus pada pemenuhan keinginan stakeholder dan tujuan penyelenggara pendidikan sesuai tupoksi masing-masing. ${ }^{31}$

Unsur utama TQM menghasilkan 4 prinsip perbaikan kualitas; kepuasan pelanggan, respek terhadap setiap orang, manajemen berdasarkan fakta, dan perbaikan berkesinambungan. Selain itu, komunikasi yang effektif dengan melibatkan staff dalam pengambilan keputusan merupakan suatu hal yang juga sangat penting. ${ }^{32}$ Vencent Gazpersz menjelaskan bahwa TQM memeiliki sepuluh unsur utama yaitu; fokus terhadap pelanggan (internal atau eksternal), obsesi terhadap kualitas, menggunakan pendekatan ilmiah, komitmen terhadap tujuan jangka panjang, membangun kerjasama tim, perbaikan kualitas secara berkesinambungan, pendidikan dan latihan, kebebasan terkendali, kesatuan visi,

${ }^{29}$ Pariyaporn Tungkunanan, Punnee Leekitchwatana Narong Pimsarn, and Siripun Chumnum, "Strategic Plan for Developing Quality Culture at Eastern School of The Office of Vocational Education Commission," ABAC Journal 28, no. 2 (2008): 56-63.hlm.59-60

${ }^{30}$ Mahmood et al., Development of Quality Culture in The Construction Industry.hlm.3

${ }^{31}$ Mursalim, "Paradigma Baru Peningkatan Mutu Satuan Pendidikan Dalam Perspektif

Total Quality Management,” Jurnal Lentera Pendidikan 13, no. 2 (2010).hlm.135

${ }^{32}$ Mursalim.hlm.137 
misi dan tujuan, dan keterlibatan serta pemberdayaan seluruh stakeholder pendidikan. TQM berhubungan dengan penciptaan budaya kualitas oleh pendidik dan tenaga kependidikan untuk menyenangkan atau memberi kepuasan kepada konsumen dengan dukungan organisasi. ${ }^{33}$

Secara praktis, peningkatan kualitas proses dalam sebuah lembaga dapat dilakukan melalui metode PDCA (Plan-Do-Check-Act). Tahapan tersebut dapat digambarkan sebagai berikut:

1. Plan, berisi penentuan proses yang perlu diperbaiki, menentukan perbaikan apa yang dipilih, dan menentukan data dan informasi yang diperlukan untuk perbaikan proses.

2. Do, berisi tentang jalannya pengumpulan data dasar tentang jalannya proses, implementasi perubahan yang dikehendaki (skala kecil), mengumpulkan data untuk mengetahui perubahan (ada perbaikan atau tidak),

3. Check, berisi langkah pemimpin untuk menafsirkan hasil implementasi (berhasil atau tidak) atau upaya pemimpin untuk memperoleh pengetahuan baru tentang proses yang berada dalam tanggung jawabnya

4. Act, berupa pengambilan keputusan perubahan mana yang akan diimplementasikan, penyusunan prosedur baku, pelatihan ulang bagi anggota terkait, dan pemantauan secara kontinyu. ${ }^{34}$

Dari beberapa penjelasan di atas dapat dipahami bahwa pengembangan budaya mutu dapat dilakukan dengan berbagai cara maupun pendekatan, dan salah satunya dengan mengimplementasikan TQM dalam manajemen organisasi. Pengembangan budaya mutu tersebut dalam dunia pendidikan titik tekannya pada guru. Dalam artian, budaya mutu dimulai dari guru sebagai aktor penting dalam peningkatan mutu pendidikan.

Metode PDCA di atas hakekatnya supervisi sebagaimana di jelaskan pada pembahasan di atas, memiliki tujuan utama mengembangkan kemampuan pembelajaran guru yang pada akhirnya akan membawa pada mutu peserta didik. Artinya supervisi di sekolah merupakan kegiatan menjamin mutu proses pendidikan atau pembelajaran yang tujuannya adalah untuk menghasilkan lulusan yang berkualitas dan berdaya saing. Kegiatan supervisi jika di integrasikan dengan konsep manajemen mutu (PDCA) berdasarkan pada kajian teoritis pada sub pembahasan di atas, maka model konseptualnya dapat berbentuk seperti pada gambar beriku:

\footnotetext{
${ }^{33}$ Mursalim.hlm.137-139

${ }^{34}$ Mursalim.hlm.139
} 


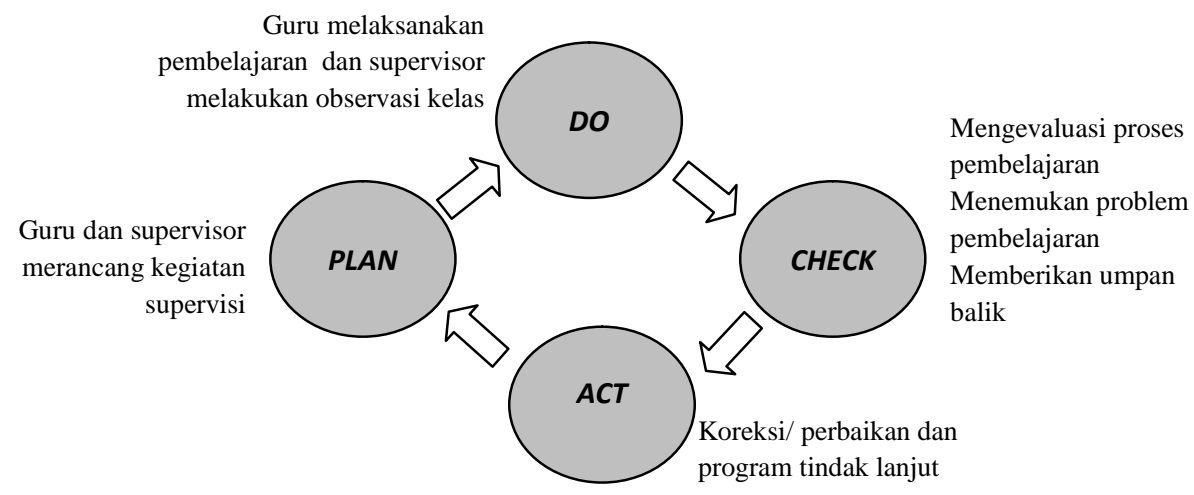

Gambar 1. Model PDCA Supervisi Pembelajaran

\section{F. Kesimpulan}

Supervisi merupakan sebuah kegiatan pengembangan kualitas pembelajaran. Kegiatan tersebut selain dapat dilakukan secara individual juga dapat dilakukan secara kelompok. Kegiatan supervisi dan penjaminan mutu keduanya merupakan konsep yang tidak berbeda, kedunya berupaya menjamin mutu proses atau layanan pendidikan. Hakekat supervisi adalah bantuan yang diberikan kepada guru guna meningkatkan mutu pembelajarannya secara berkelanjutan. Kegiatan tersebut sejalan dengan konsep dasar manajemen mutu atau manajemen mutu terpadu (total quality management) yang bertujuan untuk peningkatan mutu secara berkelanjutan atau yang dikenal dengan menciptakan budaya mutu (quality culture).

Dari berbagai kajian terkait budaya mutu dapat disimpulkan bahwa supervisi merupakan sebuah instrument dalam peningkatan mutu yang harus mampu menumbuh-kembangkan budaya mutu pada dunia pendidikan terutama pada diri guru (pendidik). Artinya budaya mutu merupakan tujuan akhir dari proses pengembangan profesional yang dilakukan pengawas atau supervisor. Guru yang telah berbudaya mutu akan senantiasa melakukan peningkatan kualitas dirinya (selft renewal capacities) sehingga mampu menciptakan pembelajaran yang efektif. Tujuan tersebut dapat tercapai jika guru atau pelaku pendidikan telah memahami dan meyakini bahwa mutu merupakan target yang ada dalam dirinya untuk dicapai, tanpa itu budaya mutu tidak akan dapat terwujud.

\section{Daftar Pustaka}

Bahrul Hayat, and Suhendra Yusuf. Benchmark Internasional Mutu Pendidikan. Jakarta: Bumi Aksara, 2010.

Budiharjo, Markus. "Berpikir Strategis? Apa Itu?" Blog Pendidikan, 2010. http://edukasi.kompasiana.com. 
Burhanudddin. Analisis Administrasi Dan Kepemimpinan Pendidikan. Jakarta:

Bumi Aksara, 1994.

Chan, Sam M., and Tuti R. Semiawan. Kebijakan Pendidikan Era Otonomi

Daerah. Jakarta: Rajawali Pres, 2005.

Depdikbud. Kurikulum Sekolah Dasar: Pedoman Pembinaan Guru. Jakarta:

Departemen Pendidikan dan Kebudayaan, 1986.

Lipham, James M., Rankin, Robb E., and Hoeh Jr, James A. The Principalship;

Concept, Competencies, and Cases. New York: Logman Inc, 1985.

Made Pidarta. Supervisi Pendidikan Kontekstual. Jakarta: Rineka Cipta, 2009.

Mahmood, Wan Yusoff Wan, Abdul Hakim Mohammed, Mohd. Saidin Misnan,

Zakaria Mohd. Yusof, and Ahmadon Bakri. Development of Quality Culture

in The Construction Industry. Malaysia: Universiti Teknologi Malaysia

ICCI, 2006.

Milisiunaite, Inga, Roma Adomaitiene, and Juozas Galginaitis. “Quality

Management As A Tool For Quality Culture Embedment: Vilnius University

Approach." Lithuania, 2009.

Mursalim. "Paradigma Baru Peningkatan Mutu Satuan Pendidikan Dalam

Perspektif Total Quality Management.” Jurnal Lentera Pendidikan 13, no. 2 (2010).

Negley, and Evan. Handbook for Effective Supervision of Instruction. Engglewood Cliffs: Prentice Hall Inc, 1980.

Ngalim Purwanto. Prinsip-Prinsip Dan Teknik Evaluasi Pengajaran. Bandung:

Remaja Rosdakarya, 2006.

Oliva, Peter F. Supervision for Today's Schools. Helper \& Row, Publisher Inc, 1976.

Purwanto. Evaluasi Hasil Belajar. Yogyakarta: Pustaka Pelajar, 2009.

Rifa'i, Andi Arif. "Urgensi Berfikir Strategis: Kerangka Kerja Pengembangan

Lembaga Pendidikan Islam.” Jurnal Akademika: Jurnal Pemikiran Islam

STAIN Metro 17, no. 2 (2012).

Sahertian, Piet A., and Frans Mataheru. Prinsip Dan Teknik Supervisi Pendidikan.

Surabaya: Usaha Nasional, 1982.

Tongsamsi, Isara, Akom Chaikeaw, Chidchanok Churngchow, and Thoedtida

Thipparat. "A Structural Equation Model of Factors Influencing the Quality

Culture of the Workforce in Thailand Public Higher Education Institutions."

International Journal of Education 4, no. 4 (2012): 16-26.

Tungkunanan, Pariyaporn, Punnee Leekitchwatana Narong Pimsarn, and Siripun

Chumnum. "Strategic Plan for Developing Quality Culture at Eastern School of The Office of Vocational Education Commission." ABAC Journal 28, no. 2 (2008): 56-63. 
|ANDI ARIF RIFA'I| Supervisi Pembelajaran Sebagai Pengembangan...

Warisan. "Hubungan Supervisi Pengajaran Dan Motivasi Kerja Dan Kinerja Guru SMU Negeri Kabupaten Pasuruan." Tesis, Universitas Negeri Malang (UM), 2003.

Willem Mantja. Bahan Ajar Pembinaan/Supervisi Pengajaran. Malang: PPS UM, 2000. 